\title{
Migration, Public Policy and Gentrification in Belleville, Paris
}

\author{
Dr Carolyn Stott \\ University of Sydney \\ carolyn.stott@sydney.edu.au
}

\begin{abstract}
This article is a study of the physical and social transformation of the Parisian quartier of Belleville since the $19^{\text {th }}$ century. Immigration history and urban renovation have interacted and contributed to or limited the gentrification of the quartier. Certain features are known to affect the type and extent of gentrification: the nature of migrant communities; the legal status of migrants; ethnic relations between migrant and host communities; poverty; crime rates; social diversity and insalubrious housing stock. These factors will be examined in relation to Belleville with a focus on the four significant stages of urban renovation: the transformation of Paris under Haussmann and its flow-on effects; the post-WWII reconstruction period, marked principally by the Plan d'Aménagement et d'Organisation Générale de Paris (PADOG); the makeover of north-eastern Paris towards the end of the $2 \mathrm{O}^{\text {th }}$ century in the form of the Plan programme de l'est de Paris; and the ongoing results and repercussions of this makeover. The evidence points to the quartier being in a stage of partial gentrification. The potential for this process to extend to a state of mature gentrification will be examined with reference to quartiers such as the Marais. ${ }^{1}$
\end{abstract}

Key words: Belleville, gentrification, migration, public policy, urban renovation

\section{Introduction}

This article will explore the factors affecting the gentrification process currently underway in Belleville. What was the catalyst for gentrification in the quartier? The migration history, commercial development and public policy implementations affecting Belleville have influenced the extent to which the quartier can be considered gentrified. A synopsis of the literature by North American and European gentrification scholars will be followed by an overview of Belleville, with particular reference to its changing population and interventionist urban policy. This will enable firstly an assessment of the current stage of gentrification in Belleville, and secondly give some indication as to what extent the process of gentrification might continue in the future.

\footnotetext{
${ }^{1}$ Acknowledgements: Thank you to Dr Elizabeth Rechniewski and Professor Peter Morgan for their valuable feedback about this article.
} 


\section{The Notion of Gentrification}

The concept of the 'neighbourhood' has become accepted in North American discussions of gentrification in urban and social planning. ${ }^{2}$ Parisian quartiers are officially contained within one arrondissement; however their borders are more difficult to define when the term is used in a wider sense in reference to an urban space that has its own distinct characteristics and promotes among its members a sense of belonging. In this context, the quartier fits Marc Augé's notion of an anthropological place as 'relational, historical and concerned with identity' (1995 p. 77). This more flexible and widely accepted application of the term allows a quartier to straddle several arrondissements, as is the case with Belleville, which, although administratively located in the 20th arrondissement, spans the 10th, 11th, 19th and 20th arrondissements in the eyes of many writers (Pennac 1985-1999), Belleville specialists (Simon 1992 p. 48; Jacquemet 1984 p. 19) and local residents.

The concept of gentrification has received considerable attention in secondary literature and commentary. If the definition of gentrification has been modified over time, geographer and scholar Neil Smith's entry in the 2000 Dictionary of Human Geography incorporates the essential elements: "The reinvestment of CAPITAL at the urban centre, which is designed to produce space for a more affluent class of people than currently occupies that space" (Smith 2000 p. 294). Early examples of the gentrification process involved primarily residential renovation and reconstruction (e.g. the working-class areas of Hampstead and Chelsea in central London observed by Ruth Glass in 1964). The term gentrification has come to incorporate commercial as well as residential redevelopment, such as in the central business districts of Boston, Philadelphia and Atlanta (Berry 1985 pp. 69-96). Stages of gentrification have been identified and defined: the first of these was the simple four-stage American model developed by Philip Clay (1979), based on his observations of large-city suburbs such as San Francisco's Western Addition and Washington D.C's Capitol Hill. Clay's first 'pioneer' stage involves the arrival of a small group of 'risk-oblivious' people. Slow expansion then follows with the recognition of the potential value of the area by real-estate agents and property developers (Stage Two). The media plays a role in the onset of the third stage of more rapid expansion by publicly validating the initial move of the pioneers to the area. According to Clay, the final move to mature gentrification occurs when the established elite business community competes with middle class professionals to purchase the best properties (pp. 57-60). Updated, more flexible models have since been proposed (Berry 1985; Bourne 1993; Hackworth \& Smith 2001; Lees Slater \& Wyly 2010) that have broader international application. Marie-Hélène Bacqué (2006) emphasises the role of public discourse in the gentrification process, both as a self-fulfilling prophecy and as a form of arbitration between various community groups working towards a common goal (p. 80). Representation in film and literature of a sector under gentrification may thus highlight the process. 3 The physical urban space thus interacts closely with and adapts to the social processes occurring within that space (Clerval 2013 p. 11). It is now widely accepted that

\footnotetext{
${ }^{2}$ I have opted to retain untranslated the French term quartier to designate an administrative sub-division of a city.

${ }^{3}$ This is the case for Belleville, for example. The representation of the quartier in Daniel Pennac's Malaussène series documented the gentrification process in train during the decade spanned by the series (1985-1995); see Stott, Carolyn, Belleville rose, Belleville rouge, Belleville noir. Représentations d'un quartier parisien du Moyen Âge jusqu'à l'an 2000 (2009), http://hdl.handle.net/2440/50422.
} 
gentrification is a global phenomenon and an inherently dynamic process (Clerval p. 9; Lees et al 2010 p. 36).

Whilst it is possible in some sectors to trace the stages from pioneer to mature gentrification, other areas become stuck for long periods at a particular phase. The speed with which and the extent to which a sector becomes gentrified depends upon economic factors affecting the sector, the city and the nation to which it belongs, as well as on local and federal government policies. Demaris Rose (1984) coined the term 'marginal gentrifier' to refer to highly-educated but modest-income earners who choose to rent or purchase apartments in inner-city areas (1996 p. 134). Opinion is mixed among gentrification scholars as to whether marginal gentrification should be considered separately from, or as part of the gentrification process. If Smith (1996) perceives marginal gentrification as important in the early stages of the gentrification process, and linked to the displacement of low-income residents, Van Criekingen and Decroly see marginal gentrification as a distinct process (2003 p. 2456).

The process of gentrification in Europe has been slow compared to the US or the UK due to various factors. Patrick Simon cites the relative inflexibility of the housing markets in European cities, where significant change in an area's population often takes a decade, as opposed to a timeframe of two to five years in North American cities (Simon in Kazepov 2005 p. 216). Anne Clerval and Antoine Fleury (2009) point to the devastation of much of London's architecture during WWII as an incentive for urban revitalization there, as opposed to other European cities such as Paris, which were largely spared and are still characterised by heritage buildings of historic importance. Collective action by local associations against public planning projects in certain sectors of some European cities has also played a role in slowing the process of gentrification (e.g. Het Oude Westen in Rotterdam, the squatting movement in large German cities such as Berlin, Hamburg and Frankfurt); however, private property development projects are notably more difficult to influence (Simon in Kazepov 2005 p. 217). Clerval (2010) has also observed that sectors with large populations of non-European Union foreigners are initially bypassed by the process of gentrification for several reasons: firstly these sectors, whether residential or commercial, are characterised by run-down living spaces; and secondly the large immigrant population living there manifests a different use of public space which does not correspond to traditional EU conventions and therefore discourages potential EU residents from settling in the sector.

It hardly needs to be said that the renovations initiated by Baron Hausmann in the 1860 s constituted a type of gentrification in Paris. The modern gentrification process 4 was not, however, observed in the French capital until the 1990 os (Clerval 2013 p. 15). This has been put down to several factors, including the French tendency towards immobility in both employment and residence, and the proliferation of public policies governing economic and social activity in France, which in turn limit flexibility; for example, the Loi de 1948 controlled rent prices until the 1980s. Since its inception in Paris, the process of gentrification has, according to Sophie Corbillé, been slow and less brutal than elsewhere (p. 164). Corbillés tracking of early gentrification in Paris begins in the late 1970 s and 1980 s with the central

\footnotetext{
${ }^{4}$ French urban researchers preferred the term embourgeoisement until the $21^{\text {st }}$ century; Edmond Préteceille (2007: 10) differentiates between the two terms, as does Delphyne Roly (2012: 13).
} 
arrondissements of the Left Bank, followed by the $13^{\text {th }}$ and $14^{\text {th }}$ arrondissements, then the Marais (spanning the first, second, third and fourth arrondissements) and the Bastille (12 ${ }^{\text {th }}$ arrondissement). Throughout the $1990 \mathrm{~s}$, gentrification was initiated in the $10^{\text {th }}, 11^{\text {th }}$ and $17^{\text {th }}$ arrondissements, and by the beginning of the 21 st century, in practically all of north-eastern Paris, including the $18^{\text {th }}, 19^{\text {th }}$ and $20^{\text {th }}$ arrondissements, the beginnings of the gentrification process were evident (Corbillé 2013 p. 3-4). Clerval describes the early stages of Parisian gentrification as a predominantly economic process along the lines of Neil Smith's rent-gap theory (2005 p. 2): the depreciation of un-renovated buildings in inner-city areas, combined with rising costs of newly-constructed housing on the outskirts of the city, encourages young, professional middle classes to value inner-city apartment living over the suburban dream of their parents, leading them to purchase run-down undervalued apartments and renovate them to their liking, therefore increasing their value considerably (Smith 1979). Other researchers point to a more cultural gentrification process in the French capital, during which the pioneer gentrifiers, often poorly-paid artists, journalists and employees in the cultural sector, are progressively joined by the upper middle classes: architects, photographers, actors, producers, cinema and theatre directors (Vivant \& Charmes 2008). In the cultural process, both the pioneer and second-stage gentrifiers prioritise what Pierre Bourdieu termed cultural and social capital over economic assets (Bourdieu 1979). Regardless of the catalyst for gentrification in Paris, the arrival of a new middle class corresponds to a displacement of lower-class residents, as occurs in other gentrified urban sectors throughout the world. Mathieu van Criekingen (2011) has advocated a change in thinking around contemporary gentrification from it being a process to a deliberate policy strategy; in a policy-led country like France, this is highly relevant and builds on the observations about public discourse and policy made by Bacqué (2006).

\section{Belleville}

Belleville perches on a hill and offers panoramic views of Paris, with which it had a longstanding and mutually dependent relationship even before it became part of the capital. Rich in pastoral lands and vineyards in the $12^{\text {th }}$ century, the area was an important source of fruit, vegetables and fresh water for Paris. It also provided the capital with building materials supplied from the local gypsum quarries. Accorded the status of parish in the $15^{\text {th }}$ century, Belleville gained considerable prosperity and autonomy, although it was to suffer in wars during the Renaissance period due to its coveted strategic position overlooking extensive plains. From the $17^{\text {th }}$ to the $19^{\text {th }}$ century, Parisians of all classes frequented the taverns and cabarets of Belleville to take advantage of the cheaper prices of local wine, which until its annexation to the capital was not subject to Parisian taxes. By the second half of the $19^{\text {th }}$ century, Belleville was the thirteenth largest city in France. The new administrative limits set at the time of its annexation to Paris in 1860 and remaining unchanged to this day significantly reduced its size and influence; half of the former city was placed in the $19^{\text {th }}$ arrondissement and the newly formed $77^{\text {th }}$ Parisian quartier of Belleville was situated in the $20^{\text {th }}$ arrondissement.

Belleville has a long-standing reputation as a vibrant, bohemian quartier, represented variously in literature and popular culture as a hotbed of rebellion, a setting for the noir genre and a refuge for immigrants (Stott 2015). Today it is perceived as the largest, most dynamic and most cosmopolitan of the Parisian 
quartiers populaires (Dunod 2012), but its reputation varies. On the positive side, the myth of Belleville as an independent and tolerant village community is selfperpetuating and reinforced in the media, in academia by socio-demographers such as Patrick Simon and in contemporary literature by the likes of Daniel Pennac and Calixthe Beyala. In line with Marc Augé's notion of an anthropological place (1992 p. 100), the quartier's residents have established a collective Bellevillois identity that is rooted in its culture and history. On the other hand, the residential issues observed throughout north-eastern Paris are noticeable in Belleville and partially linked to its cosmopolitan heritage. Promiscuity, delinquency, insecurity, insalubrious housing, difficult working conditions, family histories often marked by turmoil and despair (Corbillé p. 160) have earned the quartier the moniker of "la banlieue intra-muros" (Dunod 2012).

\section{Belleville's Changing Population}

From its transformation into an urban space in the $19^{\text {th }}$ century until the $1980 \mathrm{~s}$, the quartier was a predominantly working-class home to both artisans and manual labourers. At the end of the $19^{\text {th }}$ century, it had the reputation of being the most Parisian of quartiers, according to 1891 Census figures: $52.2 \%$ of Belleville's population was born in Paris, against an average percentage of $36.6 \%$ of Parisianborn residents per quartier (Jacquemet 1984 p. 222). From the second half of the $19^{\text {th }}$ century, workers forced out of the centre of Paris by Haussmann's radical urban transformations chose Belleville as their place of residence. Towards the end of the $19^{\text {th }}$ century, provincial migration occurred, primarily from the central region of Auvergne.

Foreign immigration took place throughout the $20^{\text {th }}$ century, beginning with the Ashkenazi Jews of Eastern Europe escaping pogroms in their homelands and seeking employment in the clothing and shoe industries already established in Belleville. Following the deportation and consequent decimation of the Jewish population of Belleville during World War II, the French government's pro-immigration policy led to the arrival in Belleville of large numbers of both Sephardic Jews and Muslims from the former French colonies in the Maghreb. Immigration to Belleville continued in waves throughout the 1960s, with the first Sub-Saharan Africans joining refugees from Europe and the Maghreb. The introduction of new immigration laws in 1974 slowed the flow of foreign arrivals into France, without ceasing it completely. Refugees from Asia were next to embark in Paris, and as the predominantly Asian $13^{\text {th }}$ arrondissement reached saturation point during the 1980s, Belleville's employment opportunities and cosmopolitan ambiance made the quartier an ideal choice of residence for newly-arrived Asians. By 1982, Belleville had lost its status as the most Parisian of quartiers, with $28.4 \%$ of foreigners living there (Simon 1993 p. 381) and almost half of the native French population having left the quartier. The quartier is often the first landing point for immigrants, principally due to the availability of cheap housing and the proximity of other immigrants. In 2009 nonFrench born residents living in Belleville comprised $34 \%$ of the population, compared to an average 15\% across Paris (Corbillé p. 39). The 2009 Census figures indicate that the largest group of non-French born residents living in Belleville is 
from the Maghreb (10.4\%), followed by Asia (7.5) and Sub-Saharan Africa (3.9\%).5 Today the $20^{\text {th }}$ arrondissement is one of the most densely populated of Paris, with more than 300 residents per hectare (Insee, 2009).

Belleville's demographics are closely linked to the patterns of urban renovation in the quartier. Public policy has greatly contributed to the progressive transformation of Belleville from a predominantly working-class quartier populaire into one with an eclectic social and cultural mix; this has in turn influenced the extent to which Belleville has been gentrified.

\section{Interventionist Urban Policy in Belleville}

In order to understand the extent of gentrification that has taken place in Belleville, four main stages of urban renovation in the quartier will be highlighted in this article: the flow-on effects of Haussmann's reforms in the 1860s; the beginning of the long-overdue transformation of the quartier a century later; the overhaul of the north-eastern belt of inner Paris towards the end of the $20^{\text {th }}$ century; and ongoing renovations initiated since the start of the $21^{\text {st }}$ century. The policies implemented during the renovation of Belleville have in common a top-down approach; if this approach was indirect in the case of the Haussmann reforms, it became progressively more direct throughout the $20^{\text {th }}$ century.

It has been claimed that the seeds of gentrification were sown by Hausmann's farreaching makeover of Paris (Clerval 2013 p. 30). The removal of the poorest residents of inner Paris to the newly-formed quartiers on the outskirts of the capital created an urgent need for housing. Belleville was an attractive residential prospect due to its proximity to the centre of the capital, its cheap accommodation and its working-class setting that was reminiscent of the village it had once been. When the renovation of inner-city Paris was more or less complete towards the end of the 1860 s, the inflated cost of living in the revamped city centre prevented the return of the working classes. ${ }^{6}$ They remained in Belleville, renting rooms in for the most part substandard housing that had been hastily constructed on porous soil from poorquality materials; owners were unwilling or unable to subsidise the upkeep of their buildings, with the result that by the end of the $19^{\text {th }}$ century, construction and renovation in the quartier had come to a standstill, whilst the population continued to expand. This lack of capital investment in a time of need, combined with the predominantly working-class population, provided suitable conditions that would ultimately lead to Belleville's gentrification, even though this would be a long time coming.

Although acknowledged in 1918 as one of Paris' îlots insalubres and hence given top priority for renovation, Belleville remained insalubrious for the first half of the $20^{\text {th }}$ century; it was not until 1958 that a plan was implemented to improve the housing situation, heralding the birth of the new Belleville, and signalling the beginning of a population transformation in the quartier. The aim of the State-initiated Plan d'Aménagement et d'Organisation Générale de Paris (PADOG) was to revitalise,

\footnotetext{
${ }^{5}$ Insee figures, 2009. The term non-French born incorporates both foreigners and immigrants, including those who have acquired French nationality. Immigrant refers to someone born outside France, but living in France. If some immigrants acquire French nationality, others remain foreigners; the immigrant status is, however, a permanent one.

${ }^{6}$ Scholars agree that the removal of the often dissident working classes from the centre of Paris was one of Haussmann's aims; Walter Benjamin coined the term 'strategic embellishment' to describe Haussmann's objective (online).
} 
decongest and decentralise Paris. Run-down buildings considered beyond redemption were targeted for demolition and replacement with apartment blocks; this was a radical process in Belleville, for example around the Place des Fêtes (19th arrondissement) that continued until 1975, and in the Couronnes, FaucheurEnvierges and Palikao sectors in and around Bas Belleville (Lower Belleville).

In 1977 Jacques Chirac was elected mayor of Paris, heralding a new era and distribution of decision-making power from purely State to incorporation at a municipal level. As the first mayor of the French capital in over a century, he was keen to make his mark. One of his main initiatives was to modify the radical renovation plans that had been carried out in Place des Fêtes, as well as on the outskirts of inner Paris on the Left Bank (13th, 14th and 15th arrondissements), in order to lessen the impact on the existing urban environment and its inhabitants. Chirac's Plan Programme de l'Est de Paris (1983), incorporating the 10th, 11th, 12th, 13th, 18th, 19th and 20th arrondissements, resulted in the creation of green spaces such as the Parc de Belleville, but despite a desire to destroy less and integrate better, much of the old Belleville was considered beyond salvation and subsequently demolished. If the 'soft urbanism' approach implemented throughout the 1980 s by architect and urban designer Antoine Grumbach in the Mare-Cascades sector of Bas Belleville as part of the major housing renovation Opération Programmée d'Amélioration de l'Habitat (OPAH) preserved the existing structure of the sector and more or less conformed to the demands of inhabitants (Yaari p. 276), other renovations initiated by Chirac demonstrated little regard for the maintenance of the traditional rural village atmosphere. Various zones d'aménagement concerté (ZAC)7 were implemented across Paris to prioritise particular sectors in need of an upgrade; the most run-down sectors were the quartiers populaires that housed predominantly semi-skilled (often immigrant) workers. In Belleville, as elsewhere, this resulted in the replacement of insalubrious, low-rise buildings with unsightly bars and towers. In a manner reminiscent of their forefathers over a century earlier following Haussmann's renovations, the working classes that had previously comprised the entire population of the quartier could no longer afford to rent an apartment in the predominantly social housing comprising the newly renovated sector, which conversely held appeal and affordability for a new middle-class segment of the population who were also eligible thanks to the introduction of logements intermédiaires in 1987. By irrevocably altering the social fabric of Belleville, these urban reforms facilitated the gentrification process; according to historian Éric Hazan, the brutal nature of the renovations points to the urban developers' desire to settle an underlying score with Belleville (p. 210), attempting to punish the quartier for its recalcitrant inhabitants of the past by erasing all physical trace of their existence.

At the end of the 1980s, a new ZAC Ramponeau-Belleville was proposed by the Paris City Council that envisaged total destruction of the Bas Belleville sector and replacement with a major commercial centre; the project would also have resulted in the displacement of a large proportion of the sector's low-income, predominantly immigrant population. The population mobilised in the form of a local association,

\footnotetext{
${ }^{7}$ Urban development in Paris since the 1970s has been variously implemented under different appellations such as ZAC, ZUS, OPAH and CUC; quartiers and arrondissements are divided into sectors according to each project. Data used in this article is sometimes cited at the level of administrative quartier or arrondissement, and elsewhere at the level of sectors, which may or may not equate to the quartier itself. Whilst attempts have been made to primarily cite data collected for the quartier of Belleville, this is not always possible.
} 
La Bellevilleuse. An inquiry was launched by the Association in 1991; experts were called in to verify the information provided by the Council, particularly in relation to the number of buildings to be razed and the subsequent accommodation of the inhabitants of these buildings. Lengthy negotiations with the Council, headed by new Mayor Jean Tiberi from 1995, finally resulted in the launch of a new plan in 1998, which proposed a massive reduction of the buildings destined for destruction from $95 \%$ to $22 \%$, and a guarantee for all inhabitants of Bas Belleville to be relocated in the sector. Tiberi's break with previous urban policies in his support for a more humane urbanism led to new constructions, exclusively social housing, being built to complement the existing structures, and restoration of the older apartment buildings in keeping with their original architectural style (Stott 2009).

The de-regularisation of rent in the $1990 \mathrm{~s}$ affected the gentrification process in Belleville. This began with the 1982 loi Quilliot proclaiming the fundamental right of all to have access to housing, voted in by the Left. An about-face occurred in 1986 with the Right legislating the loi Méhaignerie in 1986. A new compromise was finally made with the Left in the loi Malandain-Mermaz in 1989, which favoured owners over their tenants (Clerval 2013 pp. 57-58). This de-regularisation encouraged property speculation and a corresponding decline in social housing construction throughout the 1980 s and 1990 s that left its mark in Belleville, thus accelerating the gentrification process, as outlined by Clerval in accordance with Smith's rent-gap theory (2013 p. 60).

The next major phase in the quartier's urban transformation regrouped several operations under the title of OPAH du Grand Belleville (1994-2003). In 1996, the government created nine zones urbaines sensibles (ZUS) across Paris, including two in Belleville: Bas Belleville and Ménilmontant. The sectors were all earmarked for financial and social support; high unemployment relative to the rest of Paris, particularly amongst young people, the percentage of households living beneath the poverty line and the risk of segregation and/or exclusion of a sector's population were amongst the determining factors for inclusion on the list. The OPAH Bas Belleville (1998-2003) is considered by the Paris City Council as being particularly successful (APUR; Le Grand Belleville). In 2000 a new ZUS Belleville-Amandiers was declared, incorporating most of Belleville and its neighbouring quartier to the south; the sector remains a ZUS, benefitting from ongoing financial and social support (APUR 2006 pp. 23-34).

The introduction of the Loi Gayssot ${ }^{8}$ in 2000 affected the gentrification process, with its promotion of social diversity across agglomerations of more than 50,000 inhabitants by stipulating the existence of a minimum $20 \%$ social housing (APUR 2003); this applied to all Parisian quartiers. This figure was increased to $25 \%$ by the Loi ALUR in 2014 (APUR 2014). Since 2001 the Société immobilière d'économie mixte de la Ville de Paris (SIEMP) has overseen projects in Paris, including parts of Belleville, to replace insalubrious apartment buildings with social housing, and to provide financial aid for joint ownership properties in need of upgrading. A contrat urbain de cohésion sociale (CUCS) was signed by the Paris City Council in 2007, which targeted for intervention sectors of Belleville and a further thirteen quartiers situated mostly in the north-east of Paris. Partnerships between various local associations and the Council enabled successful implementation of facilities and

\footnotetext{
${ }^{8}$ The Loi Gayssot is also known as the Loi relative à la solidarité et au renouvellement urbains (SRU).
} 
support in the Belleville-Amandiers sector in seven priority areas: employment; social support structures; education, youth and sport; health; prevention of delinquency; and culture (APUR 2010 p. 75). One of incoming (2014) Paris Mayor Anne Hidalgo's preliminary projects to maintain and further increase social mixity across the capital is designed to prevent traditional working-class quartiers being over-gentrified (Vion 2014); Belleville's presence on the list of targeted addresses indicates that this plan has the potential to slow the gentrification process. Whilst recent improvements are evident in Belleville thanks to these interventions, housing is still an issue. In July 2012, a list of residences most likely to fall into disrepair was compiled by the Observatoire du Logement et de l'Habitat de Paris. The majority of the Parisian residences on the list are located in the 17th, 18th and 20th arrondissements, with $16 \%$ of the total number situated in the vicinity of Belleville (APUR 2012 p. 5).

\section{Assessment of the current stage of gentrification in Belleville}

In determining the extent to which Belleville may be classified as gentrified, we will examine the factors present in the quartier that have been identified by gentrification scholars as promoting the process, those that have been shown to limit gentrification, and those particular to Belleville that render more complex the quartier's status in the gentrification process. Precursory signs of gentrification were evident in Belleville in the 1980 s (Vivant \& Charmes 2008 p. 44) with the appearance of gentrification pioneers: increasing numbers of students and young professional couples chose the quartier as their place of residence, due to its proximity to the centre of Paris and its prevalence of cheap housing in considerable disrepair. Artists, like students, with little economic capital but much cultural capital to invest, were and continue to be attracted to Belleville for its urban lifestyle and bohemian atmosphere reminiscent of the working class quartier populaire it once was. The other major factor that made the quartier ripe for the onset of gentrification was the implementation of the urban policies detailed above, which prioritised the construction of more social housing and improvement of public spaces. These programs, implemented to a large extent by Chirac and Tiberi's rightleaning Rassemblement pour la République party, have been instrumental in the transformation of Belleville by rendering the quartier more attractive to a new class of residents and thus facilitating its progression towards full gentrification. Clerval and Fleury suggest, furthermore, that urban policies promoted under Mayor Bertrand Delanoë (2001-2014) by the Socialist Paris City Council to ostensibly slow gentrification, have actually facilitated the process with their support for cultural policies and the renovation of residential and public spaces (2009 p. 15). Examples of such policies include the CUCS and the Loi Gayssot; a lack of available space in which to construct new social housing in inner Paris resulted in existing buildings in need of renovation being targeted for conversion to social housing. The renovated apartments are larger but there are less of them, a situation which has obliged some former working-class occupants to seek accommodation elsewhere. This, combined with the fact that a percentage of social housing in France is reserved for middleclass occupancy, becomes a gentrification facilitator, especially when one takes into account the relatively small percentage of social housing compared to the private sector, which is generally not affordable for the lower classes.

The students, artists and other middle-class gentrifiers encouraged by such policies to move to Belleville are supportive of policies that facilitate improvements to public, 
green and cultural spaces, and that validate the quartier as a tourist destination. There is evidence to suggest that inhabitants in the north-eastern part of the capital are particularly attached to their quartier (Corbillé p. 111). They prioritise parks, cafés, schools, associations and community garden projects, as well as political bodies such as the conseils de quartier created in 2002, citing their existence as a major contribution to an increased sense of solidarity and collective identity. Bellevillois residents interviewed by Dunod reinforce this village spirit that perpetuates despite the disappearance of physical signs of the village populaire that used to be (2012).

Corbillé notes a similar village atmosphere in other peripheral quartiers like Charonne and Abbesses that escaped Haussmann's renovations and those that followed in the second half of the 19th century. The existence of low-rise architecture, artisanal workshops, sloping topography, narrow streets and courtyards make quartiers such as Belleville popular for those wishing to enter the property market (p. 33). Social life is based around the local cafés and public spaces, culture is not hidden in exclusive galleries, but overtly celebrated; the rue Dénoyez in Bas Belleville, for example, is a highly respected graffiti artist's paradise. Corbillé cites the testimony of the local artist network in Belleville existing in a "permissive urban space that inspires creativity" (p.152). The local artists continue to occupy workshops in the quartier, exhibiting their work during annual open days and offering classes to the disadvantaged youth.

Belleville's reputation as an incubator of fine arts extends to the music scene; Vivant and Charmes raise the quartier's artistic standing as a catalyst in its gentrification (2008). The quartier became a mecca in the 1980 s for the Parisian alternative music, artistic and political scene; musicians such as Mano Negra and the Béruriers Noirs were thus among the pioneer gentrifiers who came to Belleville to occupy squats in which they had ample space to practise and perform (p. 45). If the original squats were destroyed in the renovation process, others became available in their place, and so Belleville earned the reputation as a place of high energy and creativity. Real estate agents affirm that the artistic dimension of Belleville adds symbolic cultural and potential economic value to the quartier (p.56). Middle- and upper-class intellectuals are attracted by the changing sociocultural trend and are keen to profit from the changes instigated by the artists; this exemplifies what Sharon Zukin calls the critical infrastructure of gentrification (1989).

The physical and cultural changes from which this new class of Bellevillois residents continue to benefit have not come about easily. The artists, students and intellectuals who comprised the early gentrifiers are by nature often radical, and participate actively in the associations that are particularly numerous in the north-eastern quartiers of Paris. Corbille links their proliferation to the precarity of such quartiers, in accordance with their status as zones urbaines en difficulté (p. 141). The previously mentioned successful actions of La Bellevilleuse in overturning the radical urban interventions promoted by the Paris City Council in the 1990 s are one example of militant action by members of associations in Belleville. The artists' Association La Forge is another example of a high profile proactive local community group that, like La Bellevilleuse, was obliged in 2009 to fight for continued legal occupation of a work space occupied by its artists for 18 years (La Forge de Belleville 2009), and can attribute successful outcomes to the support of its gentrifier members. 
If the quartier's geographical proximity to the capital's centre, its bohemian atmosphere, availability of relatively cheap housing, coupled with some of the urban policies previously mentioned, have helped promote Belleville to a new class of residents, thus facilitating the gentrification process, other aspects have slowed the process. The state of disrepair of many residential buildings that made property purchase and renovation affordable to some middle-class early gentrifier residents was so extensive that certain sectors of the quartier had to be completely demolished and rebuilt. Social housing, although at $29.7 \%$ still a small percentage of the total residential property market in Belleville (APUR 2012), constitutes the vast majority of the new residential buildings in many sectors, making them less attractive to some potential buyers and permitting the working-class population to afford to stay in the quartier, renting apartments in this subsidised sector. This phenomenon has been observed by Clerval in the area surrounding the Parc de Belleville, for example; despite the impressive views and proximity to green space (two factors that are recognised as gentrification facilitators), the prevalence of social housing has so far prevented its gentrification (2010 p. 13). Vivant and Charmes have observed a similar sluggishness in the gentrification process due to the proliferation of social housing in other parts of Belleville (p. 6o).

The other major inhibitor in the gentrification of Belleville is the presence of a relatively high percentage of non-European Union immigrants, a factor observed by Clerval in several other Parisian quartiers (2010) initially bypassed by the gentrification process, and by Zukin in the US in regard to suburbs with a relatively high percentage of non-white residents (in Lees et al 2010 p. 223). Lack of financial stability limits newly-arrived non-European Union immigrants to working-class sectors, where they are a highly visible presence in their occupation of both residential and commercial spaces. The fact that their appropriation and use of public space often differs from their EU counterparts is a further limitation; this can be either a disincentive to prospective gentrifiers, or a cause of contention once they have arrived in Belleville. Simon (1995) and Pasotto (1996) noted that in Bas Belleville the middle-class occupants of the newly renovated sectors of Belleville rubbed shoulders with the remaining working-class artisans and increasing numbers of immigrants who have continued to reside in the un-renovated sectors of the quartier. Both old and new inhabitants adapt with difficulty to this cohabitation, with conflict arising between ethnic groups and their middle-class neighbours who do not share their ideological and social practices. The middle classes are destabilised by the constant occupation of public spaces by immigrants, who find comfort in clusters in the street, as is traditional practice in their villages of origin. The increasing number of shops run by and for non-EU residents of Belleville is further cause for concern for some middle-class residents, who seek more traditional French produce of a higher quality and more conventional European commercial outlets. Additional proof of their reticence to fully integrate themselves in the quartier is the fact that middle-class residents often choose to school their children outside the quartier rather than at the local schools (particularly once they have finished primary school) where the high proportion of students of non-French background has been found in some cases to impact negatively on the schools' academic programs. 9

\footnotetext{
${ }^{9}$ The zones d'éducation prioritaire are all situated in north-eastern Paris. The film Entre les murs (Laurent Cantet; 2008) and the eponymous novel by François Bégaudeau (2006) on which the film is based, show the difficult educational environment in the ZEP-classified Collège Françoise Dolto in Belleville, where conflict constantly erupts between unmotivated students and their teachers.
} 
Gentrification is a complex process that defies strict rules and interpretations. If some Bellevillois gentrifiers attempt to preserve the cosmopolitan element of the quartier and slow down its gentrification, they also unwittingly facilitate the process by helping to revalorise Belleville, justifying further investments by property developers. Their presence has, furthermore, contributed to a partial destruction of the social order with the departure of some of the original working-class residents from the quartier. If many of the gentrifiers are seen to participate actively in the Bellevillois community, and help to bring about important changes that improve the living conditions of their neighbours, this sense of goodwill is not felt by all of them. Residents interviewed by Dunod in 2012 indicate that some of the newer residents, whom they disparagingly call bobos (bourgeois-bohèmes) might choose Belleville with its working-class populaire ambiance as their place of residence, but they do not support the working-class population. Similarly, they are attracted by the exotic multicultural atmosphere, but they choose not to mix with the immigrant communities in the quartier. Corbillé cites the illegal street trade, dirty public spaces and habits, signs of poverty such as the presence of homeless people, those with mental health issues and illegal immigrants as further factors that dissuade potential middle- and upper-class buyers from purchasing in the quartier (pp. 209-210).

The gap between rich and poor is notable in the quartier, with Bas Belleville still classed as a priority area in need of ongoing support, and Haut (Upper) Belleville the choice of address for middle- and upper-class residents, particularly around the metro stations of Pyrénées and Jourdain. Cited in 2008 in as one of the top five Parisian quartiers with the most potential for growth in the housing market (Le Parisien), Belleville has continued to demonstrate a strong rise in housing prices with the average price per square metre in February 2015 at 6,302 euros, a 150\% increase on the average price in 1990, but still well below the Parisian average of 7,886 euros per square metre (Meilleurs Agents). Corbillé confirms that this steady rise that constitutes quantitative proof of the gentrification process is noticeable in other north-eastern areas such as those around the Goutte d'Or (18th arrondissement) (p. 28). For a sector to become completely gentrified there must be a proliferation of wealthy residents (Vivant \& Charmes p. 61); this is obviously not the case in contemporary Belleville, where blue-collar workers constitute the majority of residents (Mairie du 2002010 p. 7). Belleville should thus be considered to be in a state of partial gentrification.

\section{Conclusion}

The likelihood of Belleville reaching a stage of mature gentrification is uncertain, and will be affected by three main factors. Firstly, it will depend on how the quartier is seen from the outside; contemporary fiction writers, ${ }^{10}$ researchers and the media are all in a position to influence this. Clay's simple four-stage model (1979) identified the role of the media in validating an area that has embarked on the gentrification process (Stage Three). Since the appearance of the first signs of gentrification in Belleville, the media continues to present both positive and negative images of the quartier. Negative reports cite the existence of low-level prostitution, illegal street trading and the increasingly frequent random attacks on the Chinese population of

\footnotetext{
${ }^{10}$ Jérémie Guez is one such author to attest to the quartier's gentrification in Paris la nuit (2011) and Du Vide plein les yeux (2013), both published by Tengo in Paris.
} 
the quartier, ${ }^{11}$ despite Belleville displaying crime figures amongst the lowest in the capital, with crime being most prevalent in the first and the 19th arrondissements (INHESI/ONDRP Report 2010). Belleville was until 2014 the only inner Parisian quartier to benefit from a Brigade specialisée de terrain; established in January 2011 and situated around the Belleville metro station, the 25-strong unit's objective is to fight against street crime. On the other hand, positive media portrayals highlight the cosmopolitan atmosphere and village lifestyle once typical of a Paris of a bygone era. The second factor determining the degree of gentrification in the quartier in the future is the extent to which elements of the population are prepared to participate in collective action to defy public policies, as has previously occurred with some success. Given Belleville's history as a place whose inhabitants have never been afraid to fight for a cause, further victories are foreseeable. Finally, the high degree of city and government intervention in the quartier relative to urban centres throughout the world, together with the ambiguous and often unintended consequences of such intervention highlighted in this article, make Belleville an interesting case study. An examination of a quartier such as La Goutte d'Or (18th arrondissement) that is currently undergoing gentrification and that shares a similar history and population with Belleville, might further highlight the inevitability and particularities of the gentrification process in Paris.

\section{References}

'Immobilier, où profiter de la baisse ?', Le Parisien. 25.01.2013, http://www.leparisien.fr/event/priximmobilier/paris.htm, accessed on 26th of May, 2015.

Atelier Parisien d'Urbanisme (APUR), 'La loi SRU et la transition réglementaire parisienne. La question des ZAC (et des secteurs de plan-masse)'. Étude avril 2003. http://www.apur.org/etude/loi-sru-transitionreglementaire-parisienne-question-zac-secteurs-plan-masse, accessed on 26th of May, 2015.

--- 'Politique de la ville. Observatoire des quartiers parisiens.' Rapport 2006,

http://www.apur.org/sites/default/files/documents/APPA1272.pdf, accessed on 26th of May, 2015.

--- 'Évaluation du contrat urbain de cohésion sociale pour Paris 2007-2010.' Rapport de synthèse 2010.

http://www.apur.org/etude/evaluation-contrat-urbain-cohesion-sociale-paris-2007-2010-cucs-rapport-synthese, accessed on 20th January, 2013.

--- 'Outil de prévention de la dégradation des immeubles anciens à Paris - Résultats 2012'.

http://www.apur.org/sites/default/files/documents/prevention_degradation_immeubles_anciens.pdf,accessed on 20th January, 2013.

--- 'Les Chiffres du logement social à Paris', No. 55, http://www.apur.org/note/chiffres-logement-social-paris2012, accessed on 3rd December, 2013.

--- 'Le Grand Belleville, synthèse des résultats évaluatifs', 2010,

http://www.apur.org/cdrom/CD_CUCS_2010/pdf/menu3_resultats/Territoires/R\%E9sultats\%E9valuatifsterritoi res/Le\%20Grand\%20Belleville_synth\%E8se.pdf, accessed on $2^{\text {nd }}$ February, 2015.

--- 'Construire mieux et plus durable: incidence de la loi ALUR sur l'évolution du bâti parisien'. Étude décembre 2014 http://www.apur.org/etude/construire-mieux-plus-durable-incidence-loi-alur-evolution-batiparisien, accessed on 26th May, 2015.

Contrat Urbain de cohésion social pour Paris 2007-2009 (CUCS), 2010.

Augé, Marc, Non-lieux, introduction à une anthropologie de la surmodernité, La Librairie du XX $\mathrm{X}^{\mathrm{e}}$ siècle, Paris: Seuil, 1992.

--- Non-places. Introduction to an anthropology of super modernity, London / New York: Verso, 1995.

Bacqué, Marie-Hélène, 'En attendant la gentrification: discours et politiques à la Goutte d'Or (1982-2000)', Sociétés contemporaines, Vol. 3, No. 63, 2006, pp. 63-87.

\footnotetext{
${ }^{11}$ The extent of this trend was evident in the 8,500-strong demonstration against the attacks on the Chinese community in Belleville that took place on 20 June, 2010, and that began peacefully, advocating the adoption of increased security measures in the quartier, but that descended into violence between young demonstrators and non-Chinese youths.
} 
Benjamin, Walter, Paris capitale du XIX $X^{e}$ siècle, Québec, 1939,

http://www.rae.com.pt/Caderno wb 2010/Benjamin Paris capitale.pdf, accessed on 7th February, 2014.

Berry, Brian, 'Islands of Renewal in Seas of Decay', in Peterson, P. (ed.) The New Urban Reality, Washington

DC: The Brookings Institution, 1985.

Blanchot, Pascal, Deroo, Eric \& Manceron, Gilles, Le Paris Noir, Paris: Hazan, 2001.

Bourne, Larry, 'The Demise of Gentrification? A Community and Prospective View', Urban Geography,

Vol.14, No.1, 1993, pp. 95-107.

Bridge, Gary, Butler, Tim \& Lees, Loretta, Mixed Communities. Gentrification by Stealth? Bristol: Policy Press, 2012.

Bourdieu, Pierre, 'Les trois états du capital culturel', Actes de la recherche en sciences sociales, Vol. 30, No. 30, 1979, pp. 3-6.

Brooks, David, Bobos in paradise: the new upper class and how they got there, New York: Simon \& Schuster, 2000.

Charmes, Eric, La rue village ou décors? Parcours dans deux rues de Belleville, Paris: Créaphis, 2006.

Clay, Philip, Neighbourhood Renewal: Middle Class Resettlement and Incumbent Upgrading in American Neighbourhoods, Lexington, MA: D.C. Health, 1979.

Clerval, Anne, 'Le logement et l'habitat, éléments-clés du processus de gentrification. L'exemple de Paris intramuros', Journée d'étude jeunes chercheurs sur le logement et l'habitat. GIS Socio-économie de l'habitat, IUP Créteil, 2005. resohab.univ-paris1.fr/jclh05/article.php3?id article=19, accessed on 16th January, 2012.

--- 'Les anciennes cours réhabilitées des faubourgs: une forme de gentrification à Paris', Espaces et Sociétés, Vol. 1, No. 132-133, 2008, pp. 91-106, cairn.info/revue-espaces-et-societes-2008-1-p-91.htm, accessed on 28th November, 2011.

--- Les dynamiques spatiales de la gentrification à Paris Cybergeo: European Journal of Geography. Espace, Société, Territoire 505. 20.07.2010. http://cybergeo.revues.org/23231, accessed on 25th November, 2011.

--- Paris sans le peuple. La Gentrification de la capitale, Paris: La Découverte, 2013.

Clerval, Anne \& Fleury, Antoine, 'Politiques urbaines et gentrification, une analyse critique à partir du cas de Paris' L'Espace Politique Vol. 8, No. 2, 15.11.2009. espacepolitique.revues.org/index1314.html, accessed on 16th November, 2011.

Corbillé, Sophie, Paris bourgeoise, Paris bohème. La ruée vers l'Est, Paris: Presses Universitaires de France, 2013.

Dunod, Ludovic, 'Belleville, les multiples visages du Paris populaire', Les voix du monde, Radio-France Internationale (RFI), 09.06.2012, http://www.rfi.fr/emission/20120609-belleville-multiples-visages-parispopulaire/, accessed on $2^{\text {nd }}$ February, 2015.

Fikri, Mehdi, 'La Goutte d'Or, un quartier ni ghetto ni bobo'. L'Humanité. 03.07.2012,

http://www.humanite.fr/societe/la-goutte-d\%E2\%80\%99or-un-quartier-ni-ghetto-ni-bobo-500059, accessed on 3rd April, 2013.

Florida, Richard, The Rise of the creative class and how it's transforming work, leisure, community and everyday life, New York: Basic Books, 2002.

Glass, Ruth, 'Introduction: Aspects of Change', (ed) Centre for Urban Studies, London: Aspects of Change, London: MacGibbon and Kee, 1964.

Goldring, Maurice, La Goutte d'Or, quartier de France. La mixité au quotidien, Paris: Éditions Autrement, 2006.

Hazan, Éric, The Invention of Paris (trans. David Fernbach), London/New York: Verso, 2010.

Institut National des Hautes Études de la Sécurité et de la Justice (INHESJ) and Observatoire national de la délinquance et des réponses pénales (ONDRP) Rapport. Les Crimes et délits enregistrés à Paris en 2009.

Jacquemet, Gérard, Belleville au XIXe siècle: du faubourg à la ville, Paris: Éditions de l'EHESS, 1984.

La Forge de Belleville. 'Mobilisations', http://laforgedebelleville.fr/evenements/mov.html, accessed on 26th May, 2015.

Lees, Loretta, Slater, Tom \& Wyly, Elvin, Gentrification, London: Routledge, 2008.

--- The Gentrification Reader, New York /London: Routledge, 2010.

Lentschner, Keren, 'L’Immobilier s'assagit timidement en France'. Le Figaro, 04.10.2007,

http://www.lefigaro.fr/immobilier/2007/07/04/05002-20070704ARTFIG90100-

1 immobilier s assagit timidement en france.php, accessed on 17th January, 2013.

Mairie de Paris, 'Conseil de quartier Belleville. Point Urbanisme' 10.11.2011,

http://www.google.fr/url?sa=t\&rct=j\&q=\&esrc=s\&source=web\&cd=4\&ved=0CEUQFjAD\&url=http $\% 3 \mathrm{~A} \% 2 \mathrm{~F}$ \%2Fwww.mairie20.paris.fr\%2Fmairie 20\%2Fdocument $\% 3$ Fid $\% 3$ D $18784 \% 26$ id attribute $\% 3 D 127 \&$ ei=UDGyU pHTKMu4iAeN-YGwCA\&usg=AFQjCNG6b6jvRMkufz9Q1WBnQK2oVUkqqw, accessed on 13th December, 2013.

Mairie de Paris, 'Direction du développement économique, de l'emploi et de l'enseignement supérieur', Appel à marque d'intérêt pour un "marché des 5 continents » www.paris.fr, accessed on 13th December, 2013. 
Mairie du 20 $0^{\mathrm{e}}$, 'Le $20^{\mathrm{e}}$ en chiffres'. Septembre 2010. www.mairie20.paris.fr, accessed on 26th May, 2015.

Meilleurs Agents, http://www.meilleursagents.com/prix-immobilier/paris-75/, accessed on $4^{\text {th }}$ February, 2015. Pasotto, Giovanni, 'La Rénovation urbaine dans le Bas-Belleville', Théorie de la Composition urbaine, École Nationale des ponts et chaussées, 1995-1996.

Pennac, Daniel, Au Bonheur des ogres, Paris: Gallimard, 1985.

--- La Fée carabine, Paris: Gallimard, 1987.

--- La Petite Marchande de prose, Paris: Gallimard, 1989.

--- Monsieur Malaussène, Paris: Gallimard, 1995.

--- Monsieur Malaussène au théâtre, Paris: Gallimard, 1996.

--- Des Chrétiens et des maures, Paris: Gallimard, 1996.

--- Aux Fruits de la passion, Paris: Gallimard, 1999.

Préteceille, Edmond, 'Is Gentrification a Useful Paradigm to Analyse Social Changes in the Paris Metropolis?', Environment and Planning, Vol. 39, No. 1, 2007, pp. 10-31.

Roly, Delphyne, Le Nouveau Visage de Belleville: étude sociologique, Mémoire sous la direction de Thierry Paquot, 2012, http://urbanisme.u-

pec.fr/servlet/com.univ.collaboratif.utils.LectureFichiergw?ID FICHIER=1259768725318, accessed on 30th January, 2015.

Rose, Demaris, 'Rethinking Gentrification: Beyond the Uneven Development of Marxist Urban Theory', Environment and Planning D: Society and Space, Vol. 2, No. 1, 1984, pp. 47-74.

--- 'Economic Restructuring and the Diversification of Gentrification in the 1980s: a View from a Marginal Metropolis', in Caulfield, J. \& Peake, L. (eds) City Lives and City Forms: Critical Research and Canadian Urbanism, Toronto: University of Toronto Press, 1996, pp. 131-172.

Simon, Patrick, 'Belleville, un quartier d'intégration', Migrations Société, janvier-février, Vol. 4, No. 19, 1992 , pp. 45-68.

--- 'Les Quartiers d'immigration : 'ports de première entrée' ou espaces de sédentarisation ? L'exemple de Belleville', Espace, Populations, Sociétés, Vol. 2, 1993, pp. 379-388.

--- 'La Société partagée. Relations interethniques et interclasses dans un quartier en rénovation. Belleville, Paris XX', Cahiers internationaux de sociologie, No. 98, 1995, pp.161-190.

--- 'Gentrification of Old Neighbourhoods and Social Integration in Europe' in Kazepov, Yuri, Cities of Europe: Changing Contexts, Local Arrangements and the Challenge to Urban Cohesion, Malden, MA: Blackwell, 2005, pp. 210-232.

Smith, Neil, 'Toward a Theory of Gentrification: A Back to the City Movement by Capital, not People', Journal of the American Planning Association Vol. 45, No. 4, 1979, pp. 538-548.

--- 'The New Urban Frontier: Gentrification and the Revanchist City, London: Routledge, 1996.

Stott, Carolyn, Belleville rouge, Belleville noir, Belleville rose: la représentation de Belleville dans la littérature et la culture populaire, 2009, http://hdl.handle.net/2440/50422, accessed on 23rd of January, 2011.

--- 'Belleville rouge, Belleville noir, Belleville rose: the complex identity of a Parisian quartier', Portal Journal of Multidisciplinary International Studies Vol. 12, No. 1, 2015: Special Issue Geographies of Identity, http://epress.lib.uts.edu.au/journals/index.php/portal/article/view/4100, accessed on $3^{\text {rd }}$ of May, 2015. Toubon, Jean-Claude, \& Messamah, Khelifa, Centralité immigrée: le quartier de la Goutte d'Or, Paris: Harmattan, 1990.

Van Criekingen, Mathieu \& Decroly, Jean-Michel, 'Revisiting the Diversity of Gentrification: Neighbourhood Renewal Processes in Brussels and Montreal', Urban Studies Vol. 40, No. 12, 2003, pp. 2451-2468.

Vion, Anne-Sophie, 'Votre logement peut-il être préempté ?', Les Echos, 18.12.2014, http://patrimoine.lesechos.fr/patrimoine/immobilier/0204026369085-votre-logement-peut-il-etre-preempte-laliste-des-adresses-visees-a-paris-1076436.php, accessed on 4th February, 2015.

Vivant, Elsa \& Charmes, Eric, 'La Gentrification et ses pionniers : le rôle des artistes off en question', Métropoles Vol. 3, 22.09.2008. http://metropoles.revues.org/1972, accessed on 15th January, 2015 Yaari, Monique, Rethinking the French City: Architecture, Dwelling and Display after 1968, Amsterdam: Rodopi, 2008.

Zukin, Sharon, Loft living: culture and capital in urban change, New Brunswick: Rutgers University Press, 1989. 